\title{
Ultrastructural observation of the airways of recovered and susceptible pigs after inoculation with Mycoplasma hyopneumoniae ${ }^{1}$
}

\author{
Luiz Francisco Irigoyen ${ }^{2}$, William Van Alstine ${ }^{3}$, John Turek ${ }^{4}$ and L. Kirk Clark ${ }^{5}$
}

\begin{abstract}
Irigoyen L.F., Van Alstine W., Turek J. \& Clark L.K. 1998. Ultrastructural observation of the airways of recovered and susceptible pigs after inoculation with Mycoplasma hyopneumoniae. Pesquisa Veterinária Brasileira 18(1):1-7. Depto Patologia, Universidade Federal de Santa Maria, Campus Camobi, Santa Maria, RS 97119-900, Brazil.

To determine the morphological differences in the epithelium of the airways of recovered and susceptible pigs after Mycoplasma hyopneumoniae challenge, twenty-four 4-week-old $M$. hyopneumoniae-free pigs were intratracheally inoculated with $10^{7} \mathrm{ccu} / \mathrm{ml}$ of a pure low-passaged culture of the P5722-3 strain of M. hyopneumoniae challenge material. Eight pigs (group I) were challenged at the beginning of the experiment and rechallenged 3 months later. Group II pigs were also challenged at the beginning of the experiment and necropsied 3 months later. Group III pigs were challenged at the same time as the rechallenge of group I pigs. Eight nonchallenged pigs served as controls (group IV). Three days after the second challenge of group I and the first challenge of group III, and every 3 and 4 days thereafter, two pigs from each group were euthanatized by electrocution and necropsied. Samples of bronchi and lung tissue were examined using light and electron microscopy (SEM and TEM). Macroscopic lesions were observed in the lungs of all group III pigs (average $=4.74 \%$ ) and were characterized by purple-red areas of discoloration and increased firmness affecting the cranioventral aspect of the lungs. Macroscopic lesions of pneumonia in groups I and II were minimal (less than 1\%). There were no gross lesions of pneumonia in control (group IV) pigs. Microscopic lesions were characterized by hyperplasia of the peribronchial lymphoid tissue and mild neutrophilic infiltrates in alveoli. Electron microscopy showed patchy areas with loss of cilia and presence of leukocytes and mycoplasmas in bronchi of susceptible pigs (group III). The bronchial epithelium of rechallenged (group I), recovered (group II), and control (group IV) pigs was ultrastructurally similar indicating recovery of the former two groups. Although mycoplasmas were seen among cilia, a second challenge on pigs of group I did not produce another episode of the disease nor did it enhance morphological changes, suggesting that those pigs could become carriers of $M$. hyopneumoniae.
\end{abstract}

INDEX TERMS: Mycoplasma hyopneumoniae, enzootic pneumonia, swine.

RESUMO.- [Observação ultra-estrutural das vias aéreas de suínos recuperados e suscetíveis após inoculação com Mycoplasma hyopneumoniae.] Para determinar as diferenças morfológicas no epitélio das vias aéreas de suínos suscetíveis e recupe-

\footnotetext{
${ }^{1}$ Accepted for publication on August 12, 1997.

${ }^{2}$ Departamento de Patologia Veterinária, Universidade Federal de Santa Maria, Santa Maria, RS 97119-900.

${ }^{3}$ Department of Pathobiology, Purdue University, West Lafayette, IN 47907, USA.

${ }^{4}$ Department of Veterinary Anatomy, Purdue University, West Lafayette, IN, 47907 USA.

5 Department of Veterinary Clinical Sciences, Purdue University, West Lafayette, IN 47907 USA.
}

rados da infecção por Mycoplasma hyopneumoniae, 24 leitões com 4 semanas de idade, livres de infecção por $M$. hyopneumoniae, foram inoculados intratraquealmente com material contendo $10^{7} \mathrm{ccu} / \mathrm{ml}$ de cultura pura da cepa $\mathrm{P} 5722$ 3 de $M$. hyopneumoniae. Oito leitões (grupo I) foram inoculados no início do experimento e reinoculados 3 meses mais tarde, após apresentarem a doença e terem se recuperado. Os oito leitões do grupo II foram também inoculados no início do experimento e necropsiados 3 meses depois. Os leitões do grupo III foram inoculados ao mesmo tempo da reinoculação dos leitões do grupo I. Oito leitões não inoculados serviram como controles (grupo IV). Três dias após a reinoculação dos leitões do grupo I e a inoculação do grupo III e, a partir disso, a cada 2 dias, dois leitões de cada grupo 
foram sacrificados e necropsiados. Segmentos de brônquios e pulmão foram examinados em microscopia ótica e microscopia eletrônica de transmissão e de varredura. Lesões macroscópicas foram observadas nos pulmões de todos os leitões do grupo III (média: $4.74 \%$ da superfície) e eram caracterizadas por áreas firmes e avermelhadas nas porções cranioventrais. Lesões macroscópicas semelhantes foram mínimas em pulmões de leitões dos grupos I e II (menos de 1\%) e ausentes no grupo IV. As lesões microscópicas consistiam de hiperplasia do tecido linfóide peribronquial e infiltrado neutrofílico leve nos alvéolos. Na microscopia eletrônica havia lesões focais no epitélio ciliado, caracterizadas por perda de cilios e descamação de células, e presença de leucócitos e micoplasmas nos brônquios de leitões suscetíveis (grupo III). O epitélio bronquial de leitões reinoculados (grupo I), recuperados (grupo II) e controles (grupo IV) era ultraestruturalmente similar, indicando recuperação nos primeiros dois grupos. Embora micoplasmas tenham sido observados entre cilios, uma segunda inoculação em leitões do grupo I não causou outro episódio da doença nem aumentou as alterações morfológicas nos brônquios, sugerindo que esses leitões podem se tornar portadores de micoplasmas.

TERMOS DE INDEXAÇÃO: Mycoplasma hyopneumoniae, pneumonia enzoótica, suíno.

\section{INTRODUÇÃO}

Mycoplasmal pneumonia of swine or enzootic pneumonia is a chronic respiratory disease reported to be the world's most prevalent swine disease (Underdhal et al. 1980). Although the gross, microscopic and ultrastructural changes in the lungs of pigs inoculated with Mycoplasma hyopneumoniae have been described (Baskerville 1972, Livingston et al. 1972, Baskerville \& Wright 1973, Mebus \& Underdhal 1977, Underdhal et al. 1980, Tajima \& Yagihashi 1982, Blanchard et al. 1992, DeBey et al. 1992, Jacques et al. 1992), the structural response in lungs of recovered pigs following $M$. hyopneumoniae inoculation has not been investigated. Researchers, using transmission electron microscopy (TEM) in gnotobiotic pigs inoculated with $M$. hyopneumoniae, have described the presence of mycoplasmas on the bronchial and brochiolar epithelium and loss of cilia (Baskerville 1972, Livingston et al. 1972, Tajima \& Yagihashi 1982, Blanchard et al. 1992). In studies using scanning electron microscope (SEM), investigators confirmed TEM results and described the presence of mycoplasmas and damage to the cilia in the tracheal epithelium (Mebus \& Underdhal 1977, Blanchard et al. 1992). Regression of uncomplicated $M$. hyopneumoniae infection in 5 to 6 weeks, as determined by gross and microscopic examinations, has been postulated (Livingston et al. 1972). However, damage to the cilia and presence of mycoplasmas in bronchial and tracheal epithelium, as observed 16 weeks postinoculation, would indicate that infected pigs could become chronic carriers of $M$. hyopneumoniae (Underdhal et al. 1980). It is well established that recovered pigs are strongly immune to a second infection with M. hyopneumoniae (Armstrong 1983, Clark et al. 1991). It is also accepted that mycoplasma adhesion to the ciliated epithelium is important for the colonization and pathogenicity of the microorganism (Zielinski \& Ross 1992). However, it is not known whether there are significant morphologic changes in the epithelium of the airways of recovered pigs that could preclude adhesion and colonization of mycoplasmas after a second exposure with $M$. hyopneumoniae.

Thus, the purpose of this study was to determine the morphological difference between airways of recovered and susceptible pigs after M. hyopneumoniae challenge.

\section{MATERIALS AND METHODS}

Experimental animals

The pigs used in this experiment were obtained from a known Mycoplasma hyopneumoniae-free farm and were free of respiratory clinical signs when purchased. All sows and 4-week-old pigs were seronegative for antibodies to $M$. hyopneumoniae by Western blot and ELISA tests.

\section{Challenge material}

To infect the pigs of groups I, II, and III, $3 \mathrm{ml}$ of a pure lowpassaged culture of the P5722-3 strain of M. hyopneumoniae containing $10^{7}$ color changing units $(\mathrm{ccu}) / \mathrm{ml}$ were used. The pigs of group IV were not challenged and served as controls.

\section{Experimental design}

Thirty two 4-week-old pigs were selected from litters of eight sows. Four pigs from each of eight sows were assigned by litter, sex, and weight to 4 treatment groups. Group I pigs were intratracheally (IT) challenged with $3 \mathrm{ml}$ of $M$. hyopneumoniae challenge material. A second challenge (rechallenge) was performed 3 months later, after the pigs had the disease and recovered. The pigs of group II were challenged early, at the same time as the pigs of group I, and were allowed to recover until the end of the experiment. Group III pigs were challenged late in the experiment, at the same time as the second challenge of the pigs from the group I. Group IV pigs were not challenged (controls). The intratracheal challenge procedure was the same. Pigs were tranquilized and held in ventral recumbency. An endotracheal tube was passed into the larynx with the aid of a laryngoscope. A $30 \mathrm{~cm}$ long plastic intravenous catheter tube was then passed through the endotracheal tube into the trachea. Approximately $3 \times 10^{7} \mathrm{ccu}$ of virulent $M$. hyopneumoniae organisms were injected through the catheter into the trachea. Pigs were held upright for 30 seconds to allow challenge material to drain into the lungs, then were positioned in lateral recumbency for recovery. During the experiment, all pigs were housed in isolation as groups. Starting 3 days after the second challenge of group I and the first challenge of group III, and every 3 and 4 days thereafter, two pigs from each group were euthanatized by electrocution and necropsied.

\section{Clinical assessment}

All pigs were observed twice a day for at least 10 minutes for evidence of coughing; coughing pigs were individually recorded. A pig was considered to have persistent coughing if it coughed more than once for each observation period.

\section{Gross examination}

At necropsy, lung lesions were scored. A standard diagram was used to draw outlines of lesions on the dorsal surface of both the lung and the ventral surface of the accessory lobe. An image analyzer (Osteoplan Digitizer, Karl Zeiss Inc., Thornwood, New York) 
was used to determine the percentage of the lung surface affected by lesions.

\section{Bacteriology}

Lung samples of approximately $1 \mathrm{~g}$ were collected from the ventral areas of each of the four anterior lobes of each pig and examined for bacteria using routine aerobic culture media and for mycoplasma species. Using sterile techniques, the collected tissues were pooled and macerated in sterile Friis broth without antibiotics. Aliquots of the suspension were then assayed for M. hyopneumoniae using previously described techniques (Armstrong \& Friis 1981).

\section{Microscopic examination}

Lung samples were collected at necropsy from each of the four anterior lobes of each pig. Samples were fixed in $10 \%$ neutral-buffered formalin, embedded in paraffin, sectioned at 5 microns, and stained with hematoxylin and eosin using routine methods. All four lung sections from each pig were scored from 0 (no lesion) to 3 (severe lesion) for the degree of lymphocytic peribronchiolitis and alveolitis. Peribronchial reaction was scored 0 when no peribronchial nodules were observed, 1 when small nodules were in less than $25 \%$ of the lobules, 2 when small nodules were in $25-75 \%$ of the lobules, and 3 when small nodules were in more than $75 \%$ of the lobules or large nodules were in any lobule. Alveolitis was scored 0 when rare, scattered alveolar macrophages were in alveoli, 1 when 1-3 cells were in less than $50 \%$ of alveoli, 2 when 1-10 cells were in most alveoli, and 3 when alveoli were completely filled with any cell type.

\section{Ultrastructural examination}

Specimens for transmission (TEM) and scanning (SEM) electron microscopy, collected from the right cranial and middle pulmonary lobes, were fixed in $1 \%$ glutaraldehyde $/ 4 \%$ formaldehyde in phosphate buffer ( $\mathrm{pH}$ 7.3). After rinsing in phosphate buffer, samples were postfixed in $1 \%$ osmium tetroxide $/ 1.5 \%$ potassium ferrocyanide for $\mathbf{1 . 5}$ hours at $4 \mathrm{C}$. Samples were then rinsed twice in $0.1 \mathrm{M}$ phosphate buffer, dehydrated through a graded ethanol series, infiltrated with propylene oxide, embedded in epoxy resin (Poly/Bed 812, Polysciences, Warrington, PA), and cut with a Reichert Ultracut E Ultramicrotome. AJEOL JEM 100-CX transmission electron microscope was then used. Samples for SEM were postfixed in $1 \%$ osmium tetroxide, dehydrated through a graded ethanol series, critical point dried and sputter coated with gold, and observed with a ISI Super II scanning electron microscope.

\section{RESULTS}

Clinical assessment

All pigs of groups I, II, and III had an occasional nonproductive cough that started 10 to 12 days after inoculation (Table 1) and stopped 58 (group I) and 65 days (group II) after challenge. Pigs of group IV (controls) did not cough. Group III pigs coughed until the end of the experiment, and pigs of group I did not cough after the second challenge.

\section{Gross examination}

Similar typical gross lesions of mycoplasmal pneumonia characterized by dark red areas of consolidation in the cranioventral portions of the lungs were observed in pigs of groups I, II, and III (Table 2). Lungs were affected at an average for the group of $1.04 \%$ SD 0.9 (group I), $0.34 \%$ SD 0.4
Table 1. Coughing scores

\begin{tabular}{lcccc}
\hline & \multicolumn{4}{c}{ Groups $(\mathrm{n}=8)$} \\
\cline { 2 - 5 } & I & II & III & IV \\
\hline $\begin{array}{l}\text { Started } \\
\text { coughing }\end{array}$ & $12^{\mathrm{a}}$ & 11 & 10 & -b \\
$\begin{array}{l}\text { Stopped } \\
\text { coughing }\end{array}$ & $58^{\mathrm{c}}$ & 65 & $-\mathrm{d}$ & -
\end{tabular}

a Days post inoculation.

b No coughing was observed during the entire experiment.

$\mathrm{c}_{\text {No coughing after the second challenge. }}$

d Coughing persisted until the end of the experiment.

Table 2. Gross lesions

\begin{tabular}{ccccc}
\hline & \multicolumn{5}{c}{ Groups } \\
\cline { 2 - 5 } Pigs & I & II & III & IV \\
\hline 1 & $2.6^{\mathrm{a}}$ & 0.0 & 1.1 & 0.0 \\
2 & 1.1 & 0.5 & 3.2 & 0.3 \\
3 & 0.0 & 0.0 & 1.8 & 0.0 \\
4 & 1.6 & 0.8 & 5.8 & 0.0 \\
5 & 0.2 & 0.9 & 3.2 & 0.1 \\
6 & 1.3 & 0.0 & 11.3 & 0.0 \\
7 & 0.0 & 0.3 & 5.2 & 0.0 \\
8 & 1.5 & 0.2 & 6.3 & 0.0 \\
Mean \pm SD & $1.04 \pm 0.9$ & $0.34 \pm 0.4$ & $4.74 \pm 3.2$ & $0.05 \pm 0.1$
\end{tabular}

a Percentage of lung surface area with lesions.

(group II), and 4.74\% SD 3.2 (group III). In susceptible pigs (group III) gross lesions were significantly higher $(p<0.05)$ than in recovered pigs, and were seen as early as 4 days after inoculation. All pigs of this group had macroscopic lesions when necropsied. Pneumonic lesions were more severe in pigs necropsied 10 and 13 days after inoculation. Pigs from group I (rechallenged) and group II (challenged early) had minimal macroscopic lesions, and were consistent with recovering lesions. Two pigs from group IV (controls) had small focal areas of atelectasis affecting the tips of the cranial lobes, but no pneumonia.

\section{Bacteriology}

Aerobic bacteria were not cultured from pneumonic lung samples. Mycoplasma hyopneumoniae was recovered from 5 pigs of groups I, 3 pigs of group II, and 7 pigs of group III. $M$. hyopneumoniae grew in appropriate medium to an average of $10^{1.5} \mathrm{ccu} / \mathrm{ml}$ (group I), $10^{1.2} \mathrm{ccu} / \mathrm{ml}$ (group II), and $10^{3} \mathrm{ccu} /$ $\mathrm{ml}$ (group III).

Table 3. Microscopic lesions

\begin{tabular}{lcccr}
\hline & \multicolumn{4}{c}{ Groups $(\mathrm{n}=8)$} \\
\cline { 2 - 5 } & $\mathrm{I}$ & II & III & IV \\
\hline $\begin{array}{l}\text { Peribronchiolar } \\
\text { reaction }\end{array}$ & $1.3^{\mathrm{a}}$ & 1.8 & 0.7 & 0 \\
Alveolitis & 0.4 & 0.5 & 1.2 & 0
\end{tabular}

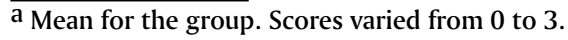




\section{Microscopic examination}

Microscopic lesions typical of mycoplasmal pneumonia were found in the lungs of all pigs with macroscopic lesions (Fig. 1). Pigs of groups I, II, and III had similar microscopic lesions of pneumonia characterized by a neutrophilic infiltrate in alveoli and alveolar septa, atelectasis of alveoli and peribronchial lymphoid infiltrates (peribronchitis). No microscopic lesions were observed in pigs of group IV (control). Peribronchial reaction was scored from 0 (no lesion) to 3 (severe) and varied from an average of 0.7 (group III) for pigs challenged late (susceptible) to 1.8 (group II) for pigs challenged three months earlier and clinically recovered (Table 3). Peribronchiolar reaction was significantly higher $(p<0.05)$ in recovered pigs than in susceptible ones, as determined by the analysis of the variance and Mann-Whitney tests. Bronchial epithelium of susceptible pigs had focal areas of loss of cilia whereas, in recovered pigs, the epithelium had normal appearing cilia. Alveolar reaction, characterized by neutrophilic infiltrates and the presence of variable amounts of mucus and edema fluid, was scored as above and varied from an average of 0.4 (group I) to an average of 1.2 for pigs of group III (Table 3). Similar mild alveolar reaction was observed in pigs that had recovered from early challenge (groups I and II) whereas in susceptible pigs (group III) the lesions were significantly $(p<0.05)$ more severe, as determined by the analysis of the variance and the Mann-Whitney tests.

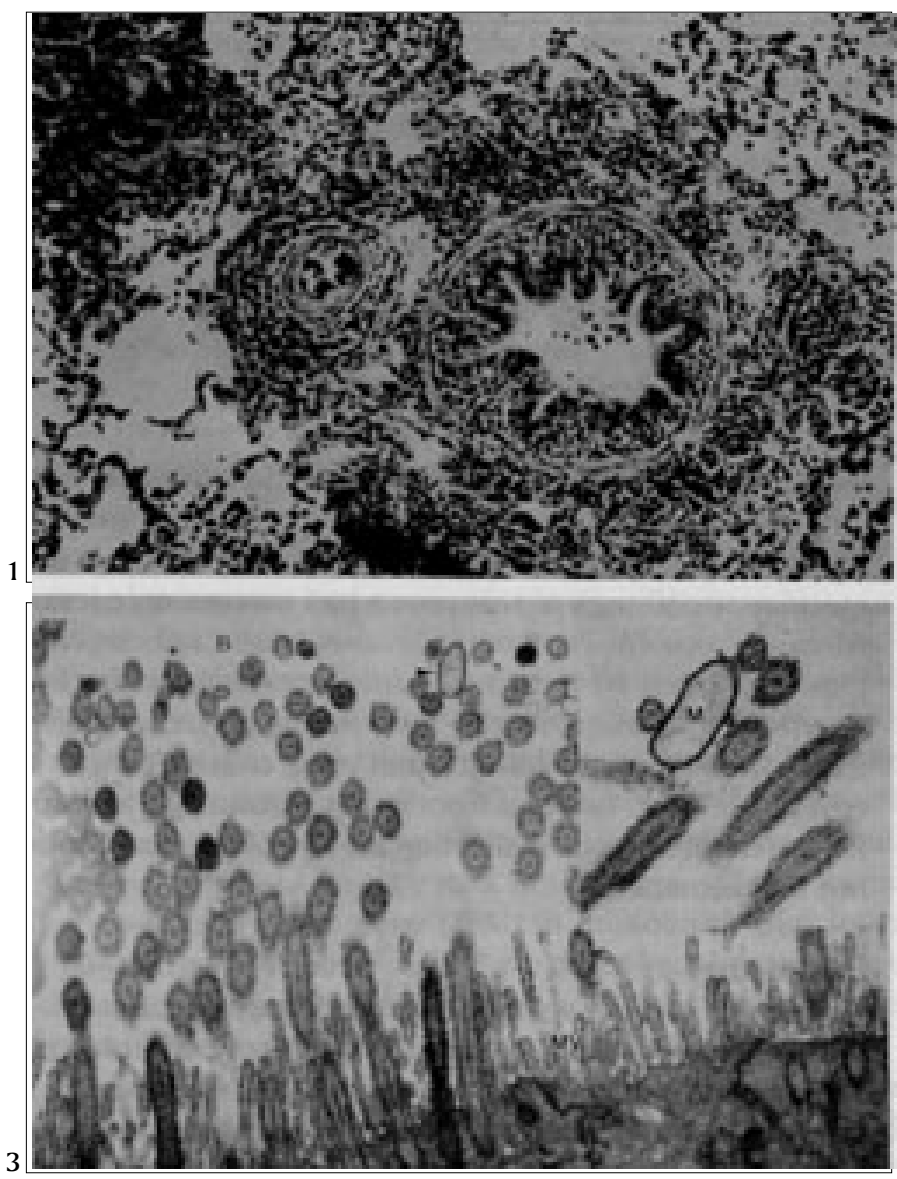

Fig. 1. Histologic features of mycoplasmal pneumonia in a susceptible (group III) pig killed 13 days after inoculation. Diffuse lymphocytic infiltrates surrounding bronchus and blood vassel(arrowheads). Adjacent alveoli contain numerous polymorphonuclear cells. $\mathrm{H} \& \mathrm{E}, \mathrm{x} 140$.

Fig. 3. Ultrastructure of bronchial epithelium from a rechallenged (group I) pig killed 3 days after second challenge. Mycoplasma (arrowhead) is among cilia (C) in the bronchial lumen (B). Cilia and microvilli (MV) are unaffected, bar $=0.5 \mathrm{~m}$. x26,000. Inset shows higher magnification of a mycoplasma (M) in proximity with cilia $(C) . \times 39,000$.
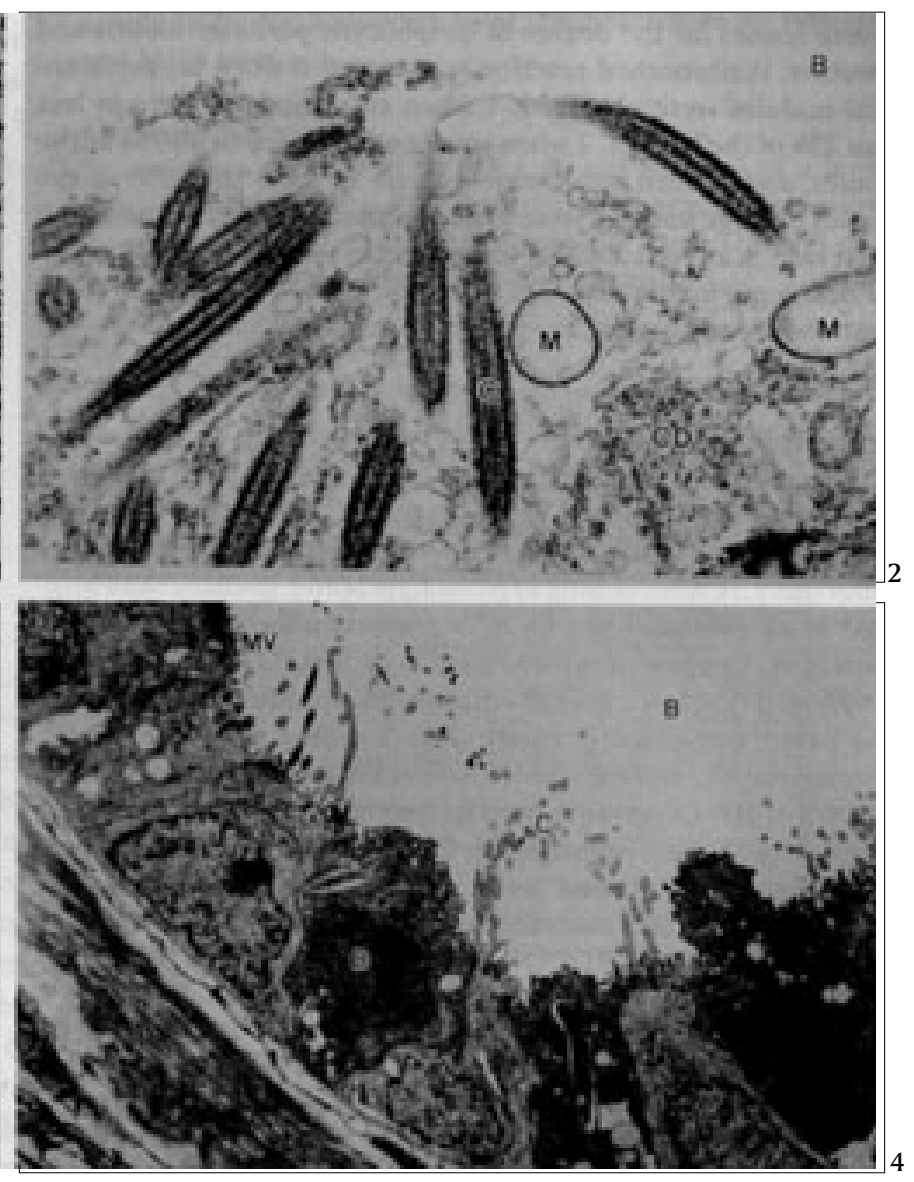

Fig. 2. Ultrastructure of the bronchial surface of a susceptible (group III) pig killed 10 days post inoculation (PI). Mycoplasmas (M) are seen among cilia $(\mathrm{C})$ and cell debri $(\mathrm{CD})$ in bronchial lumen (B), bar $=0.5 \mathrm{~m} . \times 32,500$.

Fig. 4. Ultrastructure of the bronchial surface of a susceptible (group III) pig killed 10 days post inoculation. Bronchial epithelium with absence or clumping of cilia (C). Microvilli (MV) are unaffected. Note necrotic dark epithelial cell (D) protruding into the bronchial lumen (B), bar $=2 \mathrm{~m}$. x5,000. 

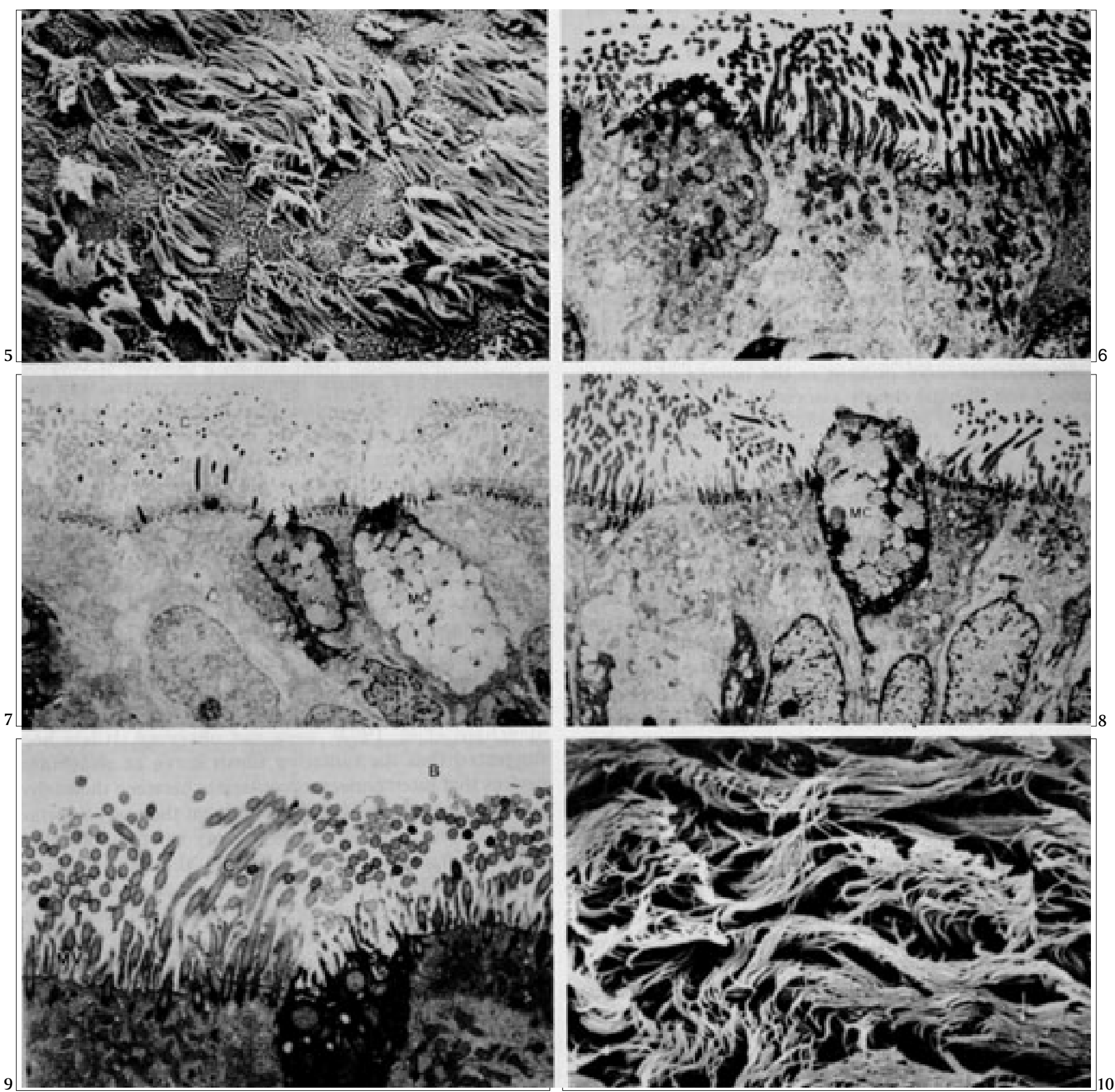

Fig. 5. Ultrastructure of the bronchial surface of a rechallenged (group I) pig killed 3 days after rechallenge. Mucus cell (MC) among ciliated epithelial cells. Normal appearing cilia (C) are in the epithelial surface, bar $=2 \mathrm{~m}$. x6,500.

Fig. 7. Ultrastructure of the bronchial surface of a recovered (group II) pig killed 13 weeks after challenge. Mucus cell (MC) opening between ciliated epithelial cells. Cilia $(C)$ are normal, bar $=2 \mathrm{~m} . \times 6,500$.

Fig. 9. Scanning electron micrograph of the bronchial surface of a susceptible (group III) pig. Patchy areas of loss or damaged cilia are seen in the bronchial epithelium of a susceptible pig killed 10 days after inoculation. $\mathbf{x} 1,400$.

Fig. 6. Ultrastructure of the bronchial epithelium of a recovered (group II) pig killed 13 weeks after challenge. Bronchial epithelial cells have normal cilia $(C)$, bar $=2 \mathrm{~m}$. x6,500.

Fig. 8. Ultrastructure of the bronchial epithelium of a control (group IV) pig. Normal epithelial cells with microvilli (MV) and cilia (C) projecting into the bronchial lumen $(B)$, bar $=1 \mathrm{~m}$. $\mathrm{x} 12,500$.

Fig. 10. Scanning electron micrograph of the bronchial epithelium of a rechallenged (group I) pig. Bronchial epithelium of a pig killed 10 days after the rechallenge showing morphologically normal cilia. x2,900. 
Ultrastructural examination

In the examination by TEM of lungs from susceptible (group III) and rechallenged (group I) pigs after inoculation, structures similar to those which have been described as mycoplasmal organisms were observed (Fig. 2,3). M. hyopneumoniae organisms were round to elongated, sometimes with a constriction in the middle portion of the body, and bound by a plasma membrane or capsule with a fuzzy material in the outer portion (Fig. 3). No radiating fibrils projecting from the outer portion of the capsule were seen. Fibrillar or finely granular material could be identified in the cytoplasm. Mycoplasmal organisms were not found by EM examination in the lungs of pigs from groups II (recovered) and IV (controls).

Mycoplasmas were present in the lumina of bronchi (groups I and III pigs) closely associated with cilia and the tips of microvilli of epithelial cells. They were found scattered near the tips of the cilia or entrapped among cilia and the tip of microvilli, usually surrounded by mucus. Mycoplasmas were not observed in close contact with the cell membrane of epithelial cells nor were they observed in alveoli or alveolar septa.

The bronchial epithelium of lungs from susceptible pigs (group III) had patchy areas with damaged or missing cilia and exposed microvilli (Fig. 4). Mycoplasmas, leukocytes and mucus were observed in the damaged areas. Damage to the ciliated bronchial epithelium was more extensive in those pigs necropsied 10 and 13 days after challenge. The bronchial epithelium from pigs of groups I (rechallenged), II (recovered), and IV (controls) was mostly ciliated with occasional mucous cells interspersed in between (Fig. 5-8). Damage to the ciliated epithelium, as observed in susceptible pigs (group III), was not found. Rare mycoplasmas were among the cilia of bronchial epithelium in one rechallenged pig; however, no associated damage to the surface structures was observed (Fig. 3).

Similar findings were obtained under SEM examination. Commonly, ciliated bronchial epithelium had a patchy loss of cilia in lungs from susceptible pigs (Fig. 9). Presence of associated mycoplasmas, mucus, and leukocytes in the lumen was also observed in lungs from two pigs of group III. The bronchial epithelium from rechallenged (group I) and recovered (group II) pigs was ultrastructurally indistinguishable from the bronchial epithelium of control pigs (Fig. $10)$.

\section{DISCUSSION}

Under these experimental conditions, clinical signs, gross and microscopic lesions of mycoplasmal pneumonia, consistent with what has been described for the disease, were observed in all inoculated pigs.

Dry, nonproductive cough was observed in pigs of groups I, II, and III; however, a second challenge in pigs of group I did not induce coughing. Gross lesions of mycoplasmal pneumonia were more severe in susceptible pigs and were most often found in the cardiac and apical lobes of the lungs, as previously described by Livingston et al. (1972). Pneumonic lesions in rechallenged (group I) and recovered (group II) pigs, killed 13 weeks PI, were very mild and indicated a nearly complete regression of the lesions. In uncomplicated Mycoplasma hyopneumoniae infection, regression of gross and microscopic lesions has been described after a period of 5 to 6 weeks (Livingston et al. 1972). A second challenge in pigs of group I did not enhance the severity of the lesions indicating that the pigs were immune to a second exposure to $M$. hyopneumoniae.

Microscopic lesions were found in the lungs of all inoculated pigs. Alveolar reaction, characterized by the presence of neutrophilic infiltrates and edema fluid, was more severe in susceptible pigs. In rechallenged (group I) and recovered (group II) pigs, the peribronchiolar reaction, characterized by nodular lymphoid hyperplasia, was more prominent than in susceptible pigs. Peribronchiolar lymphoid hyperplasia is a feature of the more chronic stages of the disease (Armstrong 1983); however, 13 weeks after infection, pigs of groups I and II had only mild peribronchiolar changes suggesting regression of the microscopic lesions, following the same pattern as the gross lesions, as was previously suggested (Livingston et al. 1972).

The ultrastructure of $M$. hyopneumoniae was similar to that described by others (Tajima \& Yagihashi 1982, Hovind-Hougen $\&$ Friis 1991). Although a thin fuzzy coat was covering the mycoplasmas in group III pigs, long radiating fibrils projecting outward from the fuzzy layer, as reported in other studies (Tajima \& Yagihashi 1982, Hovind-Hougen \& Friis 1991, Blanchard et al. 1992), were not observed. It has been suggested that the radiating fibrils serve as attachment devices that interconnect mycoplasmas between themselves and adjacent cilia and microvilli and that they are important in the colonization of the respiratory ciliated epithelium (Tajima \& Yagihashi 1982, Tajima et al. 1985). However, radiating fibrils have only been observed after staining the samples with ruthenium red, which was out of the scope of this experiment.

The significant ultrastructural lesions in susceptible pigs, as observed by TEM and SEM, were patchy areas of damage and loss of cilia over bronchial epithelial cells, and are consistent with what has been described (Baskerville 1972, Livingston et al. 1972, Baskerville \& Wright 1973, Mebus \& Underdhal 1977). Mycoplasmas were embedded among cilia and tips of microvilli of bronchial epithelial cells. In our study, only small numbers of mycoplasmas were observed in the surface of bronchial epithelium. It is possible that dosage of the inoculum and strain of the mycoplasmal organisms are factors that may account for this finding. Also, since our study was performed to describe the early morphological changes in porcine airways, lungs from susceptible pigs were examined only up to 13 days PI. High numbers of mycoplasmas have been described in later stages of the infection, between 21 and 28 days PI (Mebus \& Underdhal 1977). Mycoplasmas were not observed in alveoli as previously reported (Baskerville 1972, Livingston et al. 1972). It is possible that polymorphonuclear cells and macrophages, observed in 
alveoli, are efficient in the removal of the mycoplasmas that have reached the alveoli.

The bronchial epithelium of rechallenged (group I) and recovered (group II) pigs was ultrastructurally similar indicating that a second challenge performed in pigs of group I did not cause morphological changes. Occasional mycoplasmas were observed in normal ciliated epithelium of one pig from group I, suggesting that although mycoplasmas can attach to the cilia of recovered pigs, they do not induce lesions. Conversely, susceptible pigs, inoculated at the same time as the second challenge of group I pigs, had typical lesions of mycoplasmal pneumonia. Whether the lack of lesions in rechallenged pigs is due to the lower titers of mycoplasmas in group I pigs compared to group III pigs, or due to some down regulation of a mycoplasma virulence mechanism is not known. Perhaps a soluble toxin normally produced by adherent $M$. hyopneumoniae is not produced or is neutralized prior to contact with the epithelium. Ultrastructural findings in lungs from rechallenged and recovered pigs were undistinguishable from those of control pigs. This observation indicates that 13 weeks PI the bronchial epithelium is completely healed even though mycoplasmas can be present and suggests that these pigs could become carriers of $M$. hyopneumoniae.

\section{REFERENCES}

Armstrong C.H. 1983. Mycoplasmal pneumonia of swine. Comp. Cont. Educ. 7(5):371-377.

Armstrong C.H. \& Friis N.F. 1981. Isolation of Mycoplasma flocculare from swine in the United States. Am. J. Vet. Res. 42:1030-1032.

Baskerville A. 1972. Development of the early lesions in experimental enzootic pneumonia of pigs: an ultrastructural and histological Study. Res. Vet. Sci. 13:570-578.
Baskerville A. \& Wright C.L. 1973. Ultrastructural changes in experimental enzootic pneumonia of pigs. Res. Vet. Sci. 14:155-160.

Blanchard B., Vena M.M., Cavalier A., Le Lanic J., Gouranton J. \& Kobisch M. 1992. Electron microscopic observation of the respiratory tract of SPF piglets inoculated with Mycoplasma hyopneumoniae. Vet. Microbiol. 30:329341.

Clark L.K., Armstrong C.H., Freeman M.J., Scheidt A.B., Sands-Freeman L., \& Knox K. 1991. Investigating the transmission of Mycoplasma hyopneumoniae in a swine herd with enzootic pneumonia. Vet. Med. 86:543-550.

DeBey M.C., Jacobson C.D. \& Ross R.F. 1992. Histochemical and morphologic changes of porcine airway epithelial cells in response to infection with Mycoplasma hyopneumoniae. Am. J. Vet. Res. 53(9):1705-1710.

Hovind-Hougen N. \& Friis N.F. 1991. Morphological and ultrastructural studies of Mycoplasma flocculare and Mycoplasma hyopneumoniae in vitro. Res. Vet. Sci. 51:155-163.

Jacques M., Blanchard B., Foiry B., Girard C. \& Kobisch M. 1992. In vitro colonization of porcine trachea by Mycoplasma hyopneumoniae. Ann. Rech. Vét. 23:239-247.

Livingston C.W., Stair E.L., Underdahl N.R., \& Mebus C.A. 1972. Pathogenesis of mycoplasmal pneumonia of swine. Am. J. Vet. Res. 33:2249-2258.

Mebus C.A. \& Underdalh N.R. 1977. Scanning electron microscopy of trachea and bronchi from gnotobiotic pigs inoculated with Mycoplasma hyopneumoniae. Am. J. Vet. Res. 38:1249-1254.

Tajima M. \& Yagihashi T. 1982. Interaction of Mycoplasma hyopneumoniae with the porcine respiratory epithelium as observed by electron microscopy. Infect. Immun. 37:1162-1169.

Tajima M., Yagihashi T. \& Nunoya T. 1985. Ultrastructure of mycoplasmal capsules as revealed by stabilization with antiserum and staining with ruthenium red. Jpn. J. Vet. Sci. 47(2):217-223.

Underdhal N.R., Kennedy G.A. \& Ramos A.S. 1980. Duration of Mycoplasma hyopneumoniae infection in gnotobiotic pigs. Can. Vet. J. 21:258-261.

Zielinski G.C. \& Ross R.F. 1992. Morphologic features and hydrophobicity of the cell surface of Mycoplasma hyopneumoniae. Am. J. Vet. Res. 53:11191124. 